\title{
APPLICATION OF IBEARUGBULEM'S MODEL FOR OPTIMIZING GRANITE CONCRETE MIX
}

\author{
Ibearugbulem O.M ${ }^{1}$, Amanambu, I.K ${ }^{2}$, Elogu T.I ${ }^{3}$ \\ ${ }^{1}$ Civil Engineering Department, Federal University of Technology, Owerri, Nigeria \\ ${ }^{2}$ Civil Engineering Department, Madonna University, Elele, Nigeria \\ ${ }^{3}$ Civil Engineering Department, Madonna University, Elele, Nigeria
}

\begin{abstract}
This work aims at developing a mathematical model for predicting the compressive strength of granitic concrete using Ibearugbulem's regression model. A total of 45 cubes were cast, comprising of 3 cubes for each mix ratio of a total of 15 mix ratios. The first 11 mix ratios were used to determine the coefficients of the regression while the whole 15 was used to validate the model. The results from the model compared favourably with the experimental results. The model was tested with the statistical student $t$-test and found to be adequate at 95\% confidence level. With the model developed in this work, any desired compressive made from granite concrete can be predicted if the mix proportions are known and vice versa.
\end{abstract}

Keywords: Ibearugbulem's regression, compressive strength.

\section{INTRODUCTION}

Ibearugbulem et al (2013) observed that Scheffe's and Osadebe's models are statistical methods of concrete mix design most frequently used in Civil Engineering. These methods are quite suitable for concrete mix optimization but they are greatly limited in that a predetermined number of experiments must be carried out in order to formulate them and they can only be applied for mix ratios that fall within the predetermined observation points (Scheffe, 1958 \& 1963, Obam 1998 \& 2006, Ibearugbulem, 2008, Osadebe and Ibearugbulem, $2008 \& 2009)$. It is based on this that led to the search of an alternative method. Ibearugbulem's regression was formulated to take care of the inherent problems of the previous models (Ibearugbulem 2013).

\section{IBEARUGBULEM'S REGRESSION EQUATION}

Ibearugbulem et al (2013), gave the final model equation as

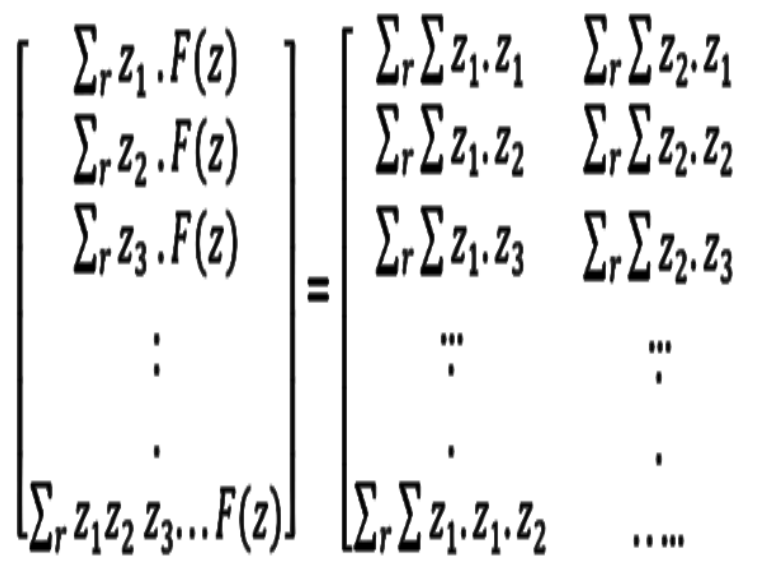

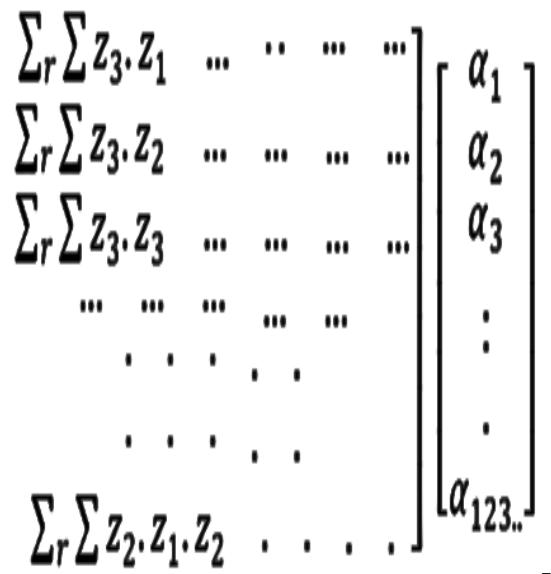

Solving the above matrix will give the values of the coefficient of regression function equation. This equation (1) can be written in a short form as

$$
[\mathrm{F}(\mathrm{z}) . \mathrm{Z}]=[\mathrm{CC}][\alpha]
$$

$\mathrm{CC}$ is always a symmetric matrix In this study we are considering a mixture of three components whose $\mathrm{CC}$ is a $7 \times 7$ matrix shown in equation (3) 


\begin{tabular}{|c|c|c|c|c|c|c|}
\hline $2 z Z 1 Z 1$ & $\varepsilon[2122$ & $\varepsilon[27123$ & ¿2Z1Z1Z2 & E[Z1Z1Z3 & E[Z1Z2Z3 & ¿2Z1Z1Z2Z3 \\
\hline $2 Z 2122$ & $2[22 Z 2$ & $2[22233$ & $2[Z 1 Z 2 Z 2$ & $2[Z 123 Z 2$ & $\Sigma[272 Z 2 Z 3$ & $\Sigma[2 Z 1 Z 2 Z 3 Z 2$ \\
\hline $22 z 123$ & 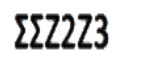 & $\varepsilon[23 Z 3$ & ¿2Z1Z2Z3 & $\Sigma[Z 123 Z 3$ & $25 Z 2 Z 3 Z 3$ & $\Sigma[2 Z 1 Z 2 Z 3 Z 3$ \\
\hline E[Z1Z1Z2 & $\sum[z 122 z 2$ & E[Z1Z2Z3 & ¿[z1Z1z2Z2 & E[Z1Z1Z2ZZ & $2[2 Z 1 Z 2 Z 2 Z 3$ & E[Z1Z1Z2Z3Z2 \\
\hline EZZ1Z1Z3 & ¿2Z1Z3Z2 & $\Sigma \Sigma Z 123 Z 3$ & ¿2z1Z1Z2Z3 & ¿2Z1Z1Z3Z3 & {$[\Sigma Z 1 Z 2 Z 3 Z 3$} & E[Z1Z1Z2Z3Z3 \\
\hline 12223 & $\sum[2 Z 2 Z 2 Z 3$ & {$[2 Z 22 Z 3 Z 3$} & E2z122Z2Z3 & [2Z1Z2ZZZZ3 & $\Sigma[2 Z 2 Z 2 Z 3 Z 3$ & E[Z1Z1Z2Z3Z3 \\
\hline
\end{tabular}

For a mixture of three components, the final model equation is given as

$$
\begin{gathered}
\mathrm{F}(\mathrm{z})=\alpha_{1} \mathrm{Z}_{1}+\alpha_{2} \mathrm{Z}_{2}+\alpha_{3} \mathrm{Z}_{3}+\alpha_{12} \mathrm{Z}_{1} \mathrm{Z}_{2}+\alpha_{13} \mathrm{Z}_{1} \mathrm{Z}_{3}+\alpha_{23} \mathrm{Z}_{2} \mathrm{Z}_{3}+ \\
\alpha_{123} \mathrm{Z}_{1} \mathrm{Z}_{2} \mathrm{Z}_{3}
\end{gathered}
$$

\section{MATERIALS USED FOR THE}

\section{COMPRESSIVE STRENGTH TEST}

Four materials were used for the experimental (laboratory) test. They include:

i. Water that is fit for drinking and taken from borehole tap in Madonna University, Akpugo Campus in Enugu State, Nigeria was used.

ii. The cement used for this test was Dangote cement, a brand of ordinary Portland cement that conforms to BS 12 (1978).

iii. River sand that was free from deleterious matters, and was well graded in the size range of $0.15 \mathrm{~mm} \leq$ $\mathrm{x} \leq 4.75 \mathrm{~mm}$ was used. iv. Granite aggregate that was free from deleterious matters and conforms to BS 882 (1992) was used. Its size range is $4.75 \mathrm{~mm} \leq \mathrm{x} \leq 19 \mathrm{~mm}$.

\section{METHOD}

The materials were batched by mass in their dried state. Cement and sand were mixed thoroughly together first and granite aggregate was introduced and the three materials were mixed thoroughly to a consistent state using manual means. After mixing properly to a consistent state the concrete was cast into the moulds and de-moulded after $24 \mathrm{hrs}$. The cubes were cured for 28 days after which they were crushed using the analogue okhard compression machine and the compressive strength was determined using equation (6) where the cross-sectional area is $22500 \mathrm{~mm}^{2}$.

Compressive Strength $=$ Failure Load $(\mathrm{N}) /$ Cross sectional Area $\left(\mathrm{mm}^{2}\right)$ $-5$

Table 1 values for $S$ and $Z$

\begin{tabular}{|l|l|l|l|l|l|l|l|l|l|l|l|}
\hline $\mathrm{S} / \mathrm{N}$ & $\mathrm{S}_{1}$ & $\mathrm{~S}_{2}$ & $\mathrm{~S}_{3}$ & $\mathrm{~S}$ & $\mathrm{Z}_{1}$ & $\mathrm{Z}_{2}$ & $\mathrm{Z}_{3}$ & $\mathrm{Z}_{1} \mathrm{Z}_{2}$ & $\mathrm{Z}_{1} \mathrm{Z}_{3}$ & $\mathrm{Z}_{2} \mathrm{Z}_{3}$ & $\mathrm{Z}_{1} \mathrm{Z}_{2} \mathrm{Z}_{3}$ \\
\hline $\mathrm{N} 1$ & 0.55 & 2 & 6 & 8.55 & 0.064327 & 0.233918 & 0.701754 & 0.015047 & 0.045142 & 0.164153 & 0.01056 \\
\hline $\mathrm{N} 2$ & 0.55 & 2.5 & 5.5 & 8.55 & 0.064327 & 0.292398 & 0.643275 & 0.018809 & 0.04138 & 0.188092 & 0.012099 \\
\hline $\mathrm{N} 3$ & 0.55 & 3 & 5 & 8.55 & 0.064327 & 0.350877 & 0.584795 & 0.022571 & 0.037618 & 0.205191 & 0.013199 \\
\hline $\mathrm{N} 4$ & 0.55 & 3.5 & 4.5 & 8.55 & 0.064327 & 0.409357 & 0.526316 & 0.026333 & 0.033857 & 0.215451 & 0.013859 \\
\hline $\mathrm{N} 5$ & 0.6 & 2.25 & 5.75 & 8.6 & 0.069767 & 0.261628 & 0.668605 & 0.018253 & 0.046647 & 0.174926 & 0.012204 \\
\hline $\mathrm{N} 6$ & 0.6 & 2.75 & 5.25 & 8.6 & 0.069767 & 0.319767 & 0.610465 & 0.022309 & 0.042591 & 0.195207 & 0.013619 \\
\hline $\mathrm{N} 7$ & 0.6 & 3.25 & 4.75 & 8.6 & 0.069767 & 0.377907 & 0.552326 & 0.026366 & 0.038534 & 0.208728 & 0.014562 \\
\hline $\mathrm{N} 8$ & 0.65 & 2 & 6 & 8.65 & 0.075145 & 0.231214 & 0.693642 & 0.017374 & 0.052123 & 0.16038 & 0.012052 \\
\hline $\mathrm{N} 9$ & 0.65 & 2.5 & 5.5 & 8.65 & 0.075145 & 0.289017 & 0.635838 & 0.021718 & 0.04778 & 0.183768 & 0.013809 \\
\hline $\mathrm{N} 10$ & 0.65 & 3 & 5 & 8.65 & 0.075145 & 0.346821 & 0.578035 & 0.026062 & 0.043436 & 0.200474 & 0.015065 \\
\hline $\mathrm{N} 11$ & 0.65 & 3.5 & 4.5 & 8.65 & 0.075145 & 0.404624 & 0.520231 & 0.030405 & 0.039093 & 0.210498 & 0.015818 \\
\hline $\mathrm{C} 1$ & 0.55 & 2.875 & 5.125 & 8.55 & 0.064327 & 0.336257 & 0.599415 & 0.021631 & 0.038559 & 0.201558 & 0.012966 \\
\hline $\mathrm{C} 2$ & 0.6 & 2.375 & 5.625 & 8.6 & 0.069767 & 0.276163 & 0.65407 & 0.019267 & 0.045633 & 0.18063 & 0.012602 \\
\hline $\mathrm{C} 3$ & 0.6 & 3.375 & 4.625 & 8.6 & 0.069767 & 0.392442 & 0.537791 & 0.02738 & 0.03752 & 0.211052 & 0.014725 \\
\hline $\mathrm{C} 4$ & 0.65 & 2.875 & 5.125 & 8.65 & 0.075145 & 0.33237 & 0.592486 & 0.024976 & 0.044522 & 0.196924 & 0.014798 \\
\hline
\end{tabular}


Four materials were used, but the components of the mix are three. They are water/cement ratio $\left(S_{1}\right)$, sand/cement ratio $\left(\mathrm{S}_{2}\right)$ and granite/cement ratio $\left(\mathrm{S}_{3}\right)$.

Note: $S=S_{1}+S_{2}+S_{3}$ and $Z_{i}=S_{i} / S$. It will observed that the actual number of elements in the concrete mix used herein is four, but this regression is keeping cement constant, thereby reducing the components for use in the regression to three. It is an improvement the present Ibearugbulem's regression has over Scheffe's and Osadebe's regression.

Substituting the values of $\mathrm{Z}_{\mathrm{i}}$ in table 1 into $\mathrm{CC}$ matrix of equation (3) gave:

\section{$\mathrm{CC}$ Matrix $=$}

\begin{tabular}{|lllllll}
0.053741 & 0.245248 & 0.4682 & 0.017174 & 0.032787 & 0.146846 & 0.01028 \\
0.245248 & 1.165412 & 2.106868 & 0.081227 & 0.146846 & 0.685551 & 0.047766 \\
0.4682 & 2.106868 & 4.140213 & 0.146846 & 0.288567 & 1.274471 & 0.0888 \\
0.017174 & 0.081227 & 0.146846 & 0.005686 & 0.01028 & 0.047766 & 0.003343 \\
0.032787 & 0.146846 & 0.288567 & 0.01028 & 0.020201 & 0.0888 & 0.006214 \\
0.146846 & 0.685551 & 1.274471 & 0.047766 & 0.0888 & 0.407111 & 0.028357 \\
0.01028 & 0.047766 & 0.0888 & 0.003343 & 0.006214 & 0.028357 & 0.001984
\end{tabular} \mid

Inverse of CC Matrix =

\begin{tabular}{|lllllll}
-979881 & -53279.7 & -325.924 & 1794966 & 1052040 & 62844.19 & -843216 \\
-53279.7 & -11780.8 & -6.32644 & 237724.2 & 60304.17 & 18514.26 & -294078 \\
-325.924 & -6.32644 & 839.9567 & 6954.5 & -9898.7 & -2479.33 & 18968.07 \\
1794966 & 237724.2 & 6954.5 & -5183080 & -1987541 & -369773 & 4908433 \\
1052040 & 60304.17 & -9898.7 & -1987541 & -986691 & -41758.2 & 576277 \\
62844.19 & 18514.26 & -2479.33 & -369773 & -41758.2 & -21778.2 & 404725.2 \\
-843216 & -294078 & 18968.07 & 4908433 & 576277 & 404725.2 & -5259490
\end{tabular}

Using the values $\mathrm{Z}_{\mathrm{i}}$ from table 1 and the laboratory compressive strength the RZ vector was obtained as;

$$
\begin{array}{ll}
\sum\left(\mathrm{Z}_{1} \cdot \mathrm{F}(\mathrm{z})\right)=18.79579 & ------6 \\
\sum\left(\mathrm{Z}_{2} \cdot \mathrm{F}(\mathrm{z})\right)=85.71375 & ------7 \\
\sum\left(\mathrm{Z}_{3} \cdot \mathrm{F}(\mathrm{z})\right)=164.9504 & -----8 \\
\sum\left(\mathrm{Z}_{1} \mathrm{Z}_{2} \cdot \mathrm{F}(\mathrm{z})\right)=5.976329 & -----9 \\
\sum\left(\mathrm{Z}_{1} \mathrm{Z}_{3} \cdot \mathrm{F}(\mathrm{z})\right)=11.50265 & ----10 \\
\sum\left(\mathrm{Z}_{2} \mathrm{Z}_{3} \cdot \mathrm{F}(\mathrm{z})\right)=51.47409 & ----11 \\
\sum\left(\mathrm{Z}_{1} \mathrm{Z}_{2} \mathrm{Z}_{3} \cdot \mathrm{F}(\mathrm{z})\right)=3.588031 & -----12
\end{array}
$$

Substituting the values of $[\mathrm{F}(\mathrm{z}) . \mathrm{Z}]$ and the inverse of $\mathrm{CC}$ matrix into Equation (2), the coefficient $[\alpha]$ of the regression which upon substituting into equation 4 gave;
$F(z)=-290.299 Z_{1}-37.3228 Z_{2}+20.5639 Z_{3}+1278.404 Z_{1} Z_{2}$ $+491.0673 Z_{1} Z_{3}+105.4005 Z_{2} Z_{3}-1905.23 Z_{1} Z_{2} Z_{3}$

Using the above final model equation, the model compressive strength is obtained thus; (see table 2)

Student t- test on the compressive cube strength was carried out to determine whether there exist significant difference between the compressive strengths from the laboratory and those from the model. The results are shown on table 2 


\begin{tabular}{|c|c|c|c|c|c|}
\hline & \multicolumn{2}{|c|}{ Table 2: LEGEND } & $D_{i}=\left(Y_{M}-Y_{E}\right)$ & \multicolumn{2}{|c|}{$\mathrm{D}_{\mathrm{A}}=\sum \mathrm{D}_{\mathrm{i}} / \mathrm{N}$} \\
\hline $\mathrm{S} / \mathrm{N}$ & $\mathrm{Y}_{\mathrm{E}}$ & $\mathrm{Y}_{\mathrm{M}}$ & $\mathrm{D}_{\mathrm{i}}$ & $\mathrm{D}_{\mathrm{A}}-\overline{\mathrm{D}}_{\mathrm{i}}$ & $\left(D_{A}-D_{i}\right)^{2}$ \\
\hline 1 & 25.48 & 25.61 & 0.13 & -0.263333 & 0.069344 \\
\hline 2 & 24.44 & 24.78 & 0.34 & -0.473333 & 0.224044 \\
\hline 3 & 22.22 & 24.06 & 1.84 & -1.973333 & 3.894043 \\
\hline 4 & 25.33 & 23.46 & -1.87 & 1.736667 & 3.016012 \\
\hline 5 & 23.85 & 25.16 & 1.31 & -1.443333 & 2.083210 \\
\hline 6 & 29.78 & 24.43 & -5.35 & 5.216667 & 27.213615 \\
\hline 7 & 20.44 & 23.88 & 3.44 & -3.573333 & 12.768709 \\
\hline 8 & 27.11 & 25.57 & -1.54 & 1.406667 & 1.978712 \\
\hline 9 & 20.89 & 24.76 & 3.78 & -3.913333 & 15.314175 \\
\hline 10 & 26.81 & 24.20 & -2.61 & 2.476667 & 6.133879 \\
\hline 11 & 23.11 & 23.90 & 0.79 & -0.923333 & 0.852544 \\
\hline 12 & 25.33 & 24.23 & -1.1 & 0.966667 & 0.934445 \\
\hline 13 & 24.89 & 24.96 & 0.07 & -0.203333 & 0.041344 \\
\hline 14 & 24.74 & 23.78 & -0.96 & 0.826667 & 0.683378 \\
\hline 15 & 24.59 & 24.32 & -0.27 & 0.136667 & 0.018678 \\
\hline Total & & & -2 & & 75.226132 \\
\hline
\end{tabular}

$\mathrm{Y}_{\mathrm{E}}=$ Experimental Result

$\mathrm{Y}_{\mathrm{M}}=$ Model Result

$\mathrm{D}_{\mathrm{A}}=\sum \mathrm{D}_{\mathrm{i}} / \mathrm{N}=-2 / 15=-0.133333$

$\mathrm{S}^{2}=\sum\left(\mathrm{D}_{\mathrm{A}}-\mathrm{D}_{\mathrm{i}}\right)^{2} /(\mathrm{N}-1)=75.226132 /(15-1)=5.373295$

$\mathrm{S}=\sqrt{5} .373295=2.318$

$\mathrm{t}=\mathrm{D}_{\mathrm{A}} * \sqrt{\mathrm{N}} / \mathrm{S}=-0.133333 * \sqrt{ } 15 / 2.318=-0.2227$

$/ \mathrm{t} /=0.2227$

$\mathrm{t}$ value from table is given as $\mathrm{t}_{\alpha / \mathrm{N}},(\mathrm{V})$.

This is equal to $\mathrm{t}_{0.05 / 15,(14)}=\mathrm{t}_{0.0033,(14)}$

From Statistics table, $\mathrm{t}_{0.0033,(14)}=3.06$ (by interpolation), whereas calculated $t$ is 0.2227

The $\mathrm{t}$ from statistical table is greater than the calculated $\mathrm{t}$ value of 0.2227 i.e. $\left(\mathrm{t}_{\text {(table) }}>\mathrm{t}_{\text {(calculated) }}\right)$, hence the Null Hypothesis is accepted and Alternative Hypothesis rejected. This means that there is no significant difference between the results predicted by the model and the laboratory.

\section{CONCLUSIONS}

The Student t-test revealed that the compressive cube strength predicted by the regression is very close to those from the experiment. The calculated $\mathrm{t}\left(\mathrm{t}_{\text {(calculated })}=0.2227\right)$ is less than the allowable $\mathrm{t}$ or $\mathrm{t}$ from statistic table $\left(\mathrm{t}_{\text {(table })}=\right.$ 3.06 ) at $95 \%$ confidence level. Thus, within $95 \%$ confidence level, one can predict the compressive cube strength of concrete made with water, cement (OPC), river sand and granite by using this model. Based on this result, it will be concluded that the "IBEARUGBULEM'S Regression" as used herein is working well and can be used to optimize granitic concrete mixes at $95 \%$ confidence level.

\section{REFERENCES}

[1] Ibearugbulem, O.M. (2006) "Mathematical models for optimization of compressive strength of periwinkle shell-granite concrete". A master's thesis submitted to postgraduate school Federal University of Technology, Owerri.

[2] Ibearugbulem, O.M. (2013) "A New Regression Model for Optimizing Concrete Mix" International Journal of Engineering Sciences \& Research Technology, vol.2 No.7, ISSN: 2277-9655, (Published).

[3] Osadebe, N.N., (2003). "Generalized Mathematical Modelling of Compressive Strength of Normal Concrete as Multi-variant function of the Properties of its Constituents components". A paper delivered at college of Engineering, University of Nigeria Nsukka.

[4] Osadebe, N. N. and Ibearugbulem, O. M. (2008) "Application of Osadebe's alternative regression model in optimizing compressive strength of periwinkle shell-granite concrete". NSE Technical transaction, vol.43, no.1, Jan. - Mar, pp.47-59.

[5] Osadebe, N. N. and Ibearugbulem, O. M. (2009), "Application of Scheffe's simplex model in optimizing compressive strength of periwinkle shell granite concrete," The Heartland Engineer, vol.4, No. 1 , pp. $27-38$. 